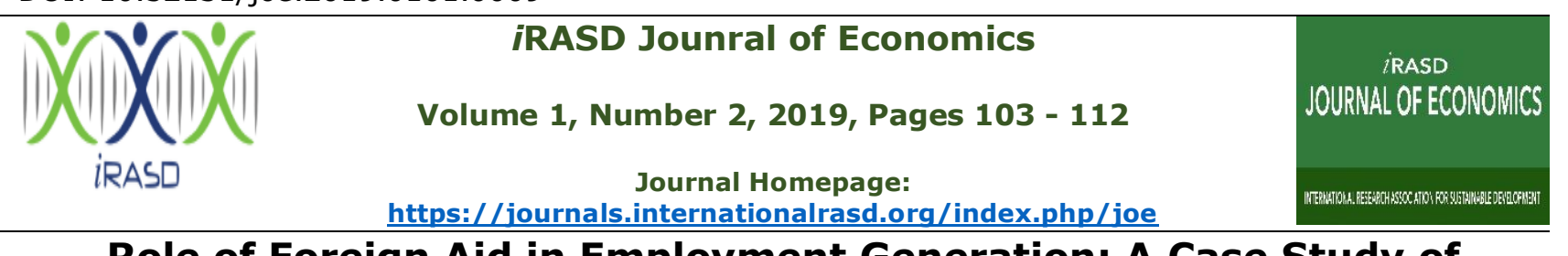

\title{
Role of Foreign Aid in Employment Generation; A Case Study of Pakistan
}

\author{
Anam Tanveer $^{1}$, Muhammad Mehran Latif ${ }^{2}$, Maryum Ziafat ${ }^{3}$ \\ ${ }^{1}$ MPhil Scholar, The Islamia University of Bahawalpur, Email: anamtanveer3@gmail.com \\ 2MPhil Scholar, Public Policy, PIDE Islamabad, Email: mehran.bhoja12@gmail.com \\ ${ }^{3}$ Masters in Islamic Banking \& Finance, IIU, Islamabad, Email: maryum.ziafat@gmail.com
}

\section{ARTICLE INFO}

\section{Article History:}

Received:

Revised:

Accepted:

August 30, 2019

Available Online: December 31, 2019

\section{ABSTRACT}

Foreign aid is very important for the development process of a country. The main aim objective of this study was to empirically investigate the relationship between foreign aid and employment generation in Pakistan. Secondary data was collected from 1980-2015 for time series data analysis. World Development Indicators and the Pakistan Economic Survey were the main sources of data (World Bank, 2020). ARDL model used for the data analysis. Employment level was used as a dependent variable, and foreign aid, Economic Growth (GDP), Gross Fix Capital Formation (GFCF), government expenditure, participation rate, and exports were used as independent variables. Form the results of the study, and it was clear that foreign aid and employment level have a positive and significant association in Pakistan. The study concludes that foreign aid has positively contributed to employment generation.

This research received no specific grant from any funding agency in the public, commercial, or not-for-profit sectors.

\section{OPEN O ACCESS}

(C) 2019 The Authors, Published by iRASD. This is an Open Access Article under the Creative Common Attribution Non-Commercial 4.0

Corresponding Author's Email: anamtanveer3@gmail.com

Citation: Tanveer, A., Latif, M. M., \& Ziafat, M. (2019). Role of Foreign Aid in Employment Generation; A Case Study of Pakistan. IRASD Journal of Economics, 1(2), 103-112.

https://doi.org/10.52131/joe.2019.0101.0009

\section{INTRODUCTION}

\subsection{Background of the Study}

The economic system of Pakistan is in large part relies on foreign capital inflow. It is extremely useful for employment generation. Foreign aid development in employment, measured as a very powerful factor for the country like Pakistan. Since independence Pakistan is facing issues in distinct forms like war, earthquake, flood, political setting and terrorism, and many others. These shocks make a disturbance to the commercial efficiency of the rustic with passaging time. As a result, Pakistan is dealing with such a lot of financial issues; financial stay low, prime inflation rate, and lack of overseas funding. To fill saving and funding hollow in developing world localities overseas aid has been a big supply of exterior financing over the past several a long time.

Generally, foreign aid is considered an infamous topic, especially when it is discussed about employment technology in the recipient country. When people discuss foreign aid's impact on the employment technology of the recipient country, then it is considered an infamous topic. The needs for which it is assigned, the phrases, conditions under which it is relocated stock of foreign aid and the time lag between overseas assist and its effect are essential. Unfamiliar kinds of overseas aid will impact on technology over weird classes. When Pakistan has signed mutual defence aid agreements, the foreign aid increased many folds at the time of cold war decade. We may also visualize the help inflow of the 1980s, which may 103 
additionally in the standpoint of Afghanistan battle. Aid inflow to Pakistan used to be once additional dropped after 1998 nuclear tests and armed forces buyout in 1999. Most contemporary aid incursion, effects from Pak-US ties after 9/11.

Pakistan is still lagging in social indicators, and people have no health facilities. Foreign aid and government programs have contributed to general employment technology, and to put it on the market social and political signs. Pakistan, since its inception, has been depending on the overseas provision to make stronger its development projects. There are macroeconomic imbalances in developing countries, but investment increases the speed of growth. Recently, high investment and has helped Pakistan for economic growth and to improve the current account deficit. Several construction programs introduced through donor and multilateral investment agencies to make upper financial movements and reach the most sensible enlargement fees in recipient nations (Ellahi \& Ahmad, 2011). Foreign aid is helping Pakistan to encounter the capacity development of institutions and to meet the public expenditures.

Every country considers infrastructure building and stimulates employment generation. The inflow of foreign aid towards Pakistan was always good, but the story is the same as in other developing countries. As a result, Pakistan becomes more aid-dependent due to no major reforms in the economic model. Foreign aid harms Pakistan, and it is difficult for the government to fulfil financial responsibility (Butt \& Javid, 2013). Bhattacharjee (2015) discussed Pakistan and china's relationship, especially about CPEC that how it would end the energy crisis and joblessness in Pakistan. The researcher investigated the effectiveness of aid in his study and focused on the debate of aid policy and its effect on financial development. Consider that the labor pressure is rising every year; however, the alternatives for employment are declining at a fast fee. Male unemployment has larger within the remaining 20 years, whereas female unemployment has decreased.

Pakistan has used mostly to finance discrete investment projects like building schools, building roads, dams, power projects, and motorways. Chenery and MacEwan (1966) concluded that foreign aid played a role in domestic investment and savings. It provides the economy with a chance to become economically sovereign finally. However, foreign aid has reduced poverty but not contributed well to GDP growth but effected in a limited way (Ishfaq, 2004). Due to CPEC investment in power and infrastructure projects, the economy has performed well (SBP, 2018). The gap between rich and poor has not lessened yet. In future CPEC will boost Pakistan's economy and livelihood of people.

This study conducted with aiming to take a look at the effect of overseas assist on employment technology and to provide the policy suggestions on the base of the findings. More particularly, the paper will provide the focal point with the core query that 'how' and 'how far' world assist has affected the employment, GDP, public expenditure, participation rate, exports, GFCF in Pakistan. This study has provided a useful understanding of stable economic policies and foreign aid. Moreover, it will help the policymakers to cater to the issue of aid efficacy.

\section{LITERATURE REVIEW}

In the literature, foreign aid and employment association is studied and arranged with the situation of Pakistan and other countries' policies.

Pohwani, Khoso, and Ahmed (2019) revealed in their research about the relevance of FDI and sustainable development that FDI is slightly optimistic with sustainable development as well as with its components. They maintained through their study that FDI has a significant impact on economic growth in short-run, while, insignificant relationship with growth in the long run. Shah, Hasnat, Cottrell, and Ahmad (2020) used the domain of electricity consumption an FDI relationship. They explained that there is a significant relationship among electricity consumption and foreign aid. Furthermore, electricity consumption will increase if the industry and production sector will use it, and it plays an important role in the economy of a country. 
Salman and Feng (2010), in their research, explained the three decades of foreign aid in Pakistan (1987-2007). The research analysed that there was a good relationship between foreign aid and GDP and economic has a direct impact on their relationship in Pakistan. A study by Malik, Chaudhry, and Javed (2011) explained the relationship between globalization and employment. They have found that FDI, remittances, and economic size have created employment in the short run. But globalization negatively affected employment because of the imbalanced relationship between internal and external due to the political dimension.

Siddiqui (2006) stated that aid benefits gained by East Asia but South Asia are lagging in this matter. Thus, due to foreign aid, government spending helped East Asia. Anwar (2004) analysed that Capital inflow, foreign aid, and remittances played a very important role in Pakistan's economy form 1960-1987. A paper by SARSOUR, NASER, and ATALLAH (2011) discussed the monetary and societal outcomes of foreign aid in Palestine. They analysed that sustainable growth is out of reach because international aid is eaten up and has not been invested. All aid was provided on the base of political consideration, and it was not for harmony and production.

Bakare (2011) inspected foreign aid in Sub-Sahara Africa on the base of the macroeconomic effect. It is proved from results that foreign aid has not effectively used for the promotion of growth and investment. Corruption was the main reason which crowded out investment and capital formation. Research conducted by Hye, Shahbaz, and Hye (2010) revealed that in developing countries, FDI had played an important role to stimulate the economy. Mullick (2004) investigated the economic growth during the war on terrorism and USA financial aid to Pakistan. The log-log abnormal, least square method used for the aim. The effects confirmed that the economic cost of changing into a pioneer within the battle in opposition to terrorism had exceeded the benefits that extra monetary reimbursement in the type of financial assist was essential from the US to ignite higher financial expansion in Pakistan and supported Pakistan's financial growth is in the best interest for each nation.

Ali and Ahmad (2013) explained income disparities and foreign aid effects on different sectors. Income inequality and foreign aid have a negative association, while FDI has a positive impact. Shirazi, Mannap, and Ali (2009) analysed the effectiveness of international aid on a human building. Education, life expectancy, human development index variables used within the learning about. Vector Error Correction type used within the study. The results showed that economic growth induced official construction help and as far as schooling index, human building index, and lifestyles expectancy index involved.

Brecher and Abbas (2005) discussed foreign, employment, external debt, and payment. Mahmood (1997) discussed the aid and growth periods of Pakistan. A study by Javid and Qayyum (2011) investigated the macroeconomic policies, and the findings of the study have supported that actual gross domestic product has an unfavourable relationship, while the aid policy interactive term and actual gross domestic product have an important positive dating.

Khan and Ahmed (2007) analysed foreign aid either is a curse or a blessing. Their results showed that economic activities enhanced by investment and aid in Pakistan. Mallik (2008) incited about the consequence of international support on financial expansion. Per capita actual gross domestic product, support, investment, and trade openness variables used in this learn about. Findings showed that a long-run relationship exists between per capita real gross domestic product aid as a percentage of the gross home product, investment as a share of the gross home product, and openness.

Nowak-Lehmann, Martínez-Zarzoso, Herzer, Klasen, and Cardozo (2013) investigated the stabilization impacts of migrant remittances to Pakistan. Remittances, reliable development aid, and overseas direct investment variables used in the study. Structural vector autoregressive type used within the find out about. Results confirmed that remittances flow to Pakistan has positive consequences in the economy.

The connection has been explored by Shahzad, Ahmed, Khiliji, and Ahmed (2011) between the expenditure and loan taken by the government of Pakistan. Research work by Faridi, Chauhdhry, and Ansari (2012) has done on the fiscal decentralization and employment opportunities that can be generated as an alternate option. The ordinary, least 105 
square method used in the find out about decentralized expenditure system on employment growth whilst decentralization in the source of revenue is not appropriate for employment generation. Poverty and inequality are lowering employment in Pakistan, so fiscal autonomy is essential for developing more employment choices in Pakistan.

Rashid, Anwar, and Torre (2014) evaluated the effect of in a foreign country improve, socioeconomic, and circle of relatives making plans techniques enter on fertility in Pakistan. Foreign lend a hand for well-being according to capita, crude get started fee, shopper price index, family literacy rate, number of LHVs as a circle of relatives planning program inputs variables used throughout the know about. Results showed that foreign aid and literacy are negatively associated with fertility in the short run. Khan et al., (2019) worked to assess the donor agencies intervention in the educational sector, and they established the comment that proactive role of agencies is important for the success of projects.

\section{DATA AND METHODOLOGY \\ 3.1. Data Source and explanation of variables}

In this chapter, a detailed discussion has been carried out for the employment generation and foreign aid. This has also checked the long and short-run effects of both. This study has covered data from the period of 1980-2015. This data was taken from the World Development Indicators, State Bank of Pakistan, and the Pakistan Economic Survey (World Bank, 2020).

This study used variable employment which played a role as a dependent, while explanatory variables are Foreign Aid (current US\$), GDP, Government Expenditure, Participation Rate (\% of total population age 15+national estimate), Gross Fixed Capital Formation (\% of GDP) Exports (current US\$).

\subsection{Functional Form}

Double log functional form is used in this thesis, which means that the econometric technique was applied to data but after taking their natural log.

$\ln E M P=\beta+\beta 1 \ln A I D+\beta 2 \ln G D P+\beta 3 \ln G O V T-E X P N+\beta 4 \ln L F-P A R T I+\beta 5 \ln G F C F+\beta 6 \ln E X P R$

Table 1

Explanation of Variables

\begin{tabular}{lc}
\hline \multicolumn{1}{c}{ Sub-Name of variables } & Variables \\
\hline EMP & Employment \\
AID & Foreign AID \\
GDP & GDP Per Capita \\
LF PARTI & Labour Force Participation \\
GFCF & Gross Fixed Capital Formation \\
EXPR & Exports \\
GOVT EXPN & Government Expenditure \\
\hline
\end{tabular}

\subsection{Econometric Methodology}

There are quite a lot of tactics for checking the Co-integration analysis. Econometric Literature has plentiful econometric techniques to research Co-integration Relationships among economic variables. The popular approaches are the well-Known Residual founded approach proposed via Engle and Granger in 1987 cited by Kanioura and Turner* (2005) and the Maximum Likelihood-based manner proposed by the use of Johansen and Julius in 1990 cited by (Silk \& Joutz, 1997). In making use of the Co-integration method, we need to decide the order of integration for every variable. When there are over two I (1) variables within the instrument, the Maximum probability approach of Johansen and Julius has the convenience over the Residual-based approach of Engle and Granger. Alternatively, this approach requires the identical order of integration that variables have. To triumph over this downside, a research paper of (Pesaran \& Smith, 1995) proposed a singular means, and they referred the 
ARDL for the Co-integration. Researchers accept the ARDL although it is or not in the order of integration that is I (0) and purely I ( 1 ) or it may mutually Co-integrate.

\subsubsection{Unit Root Test}

It is the fact that time series data has the quality to make information non-stationary, that why spurious regression issues rose after this quality. To make stationary, the data ADF is used for the level data.

\subsubsection{Cointegration}

We have examined the Co-integration via the ARDL Bounds test. The series of variables was in line with $\mathrm{I}(0)$ or I (1) in the presence of variables I (2). Pesaran, Shin, and Smith (2001) explained that in ARDL coefficients make long-run equilibrium, whereas ECM shows short-run and long-run equilibrium.

$$
\begin{gathered}
\Delta(L E M P) t=a_{0} \sum_{i=1}^{P} \alpha 1 \Delta(L A I D) \tau-1+\sum_{i=1}^{P} \alpha 2 \Delta(L G D P) \tau-1+\sum_{i=1}^{P} \alpha 3 \Delta(L E X P R) \tau-1+ \\
\sum_{i=1}^{P} \alpha 4 \Delta(L G F C F) \tau-1+\sum_{i=1}^{P} \alpha 5 \Delta(L F-P A R T I) \tau-1+\sum_{i=1}^{P} \alpha 6 \Delta(L G O V T+E X P N) \tau-1+\gamma 1(L A I D) \tau- \\
1+\gamma 2(L G D P) \tau-1+\gamma 3(L E X P R) \tau-1+\gamma 4(L G F C F) \tau-1+\gamma 5(L F-P A R T I) \tau-1+\gamma 6(L G O V T+ \\
E X P N) \tau-1 \\
\mathrm{a}_{1}, \mathrm{a}_{2} \ldots \ldots . . \mathrm{a}_{5} \text { explain the short-run dynamics of the model. Parameters } \mathrm{r} \\
\gamma_{1}=\gamma_{2}=\gamma_{3}=\gamma_{4}=\gamma_{5}=\gamma_{6} \text { showed the long-run relationship. So the null hypothesis is } \\
\mathrm{H}_{0}: \gamma_{1}=\gamma_{2}=\gamma_{3}=\gamma_{4}=\gamma_{5}=\gamma_{6}=0 \\
\mathrm{H} 1: \gamma_{1} \neq \gamma_{2} \neq \gamma_{3} \neq \gamma_{4} \neq \gamma_{5} \neq 0
\end{gathered}
$$

It was clear that $\mathrm{H}_{0}$ rejection will show that there is the existence of cointegration. So after existence, we move to net stop that was testing of long and short-run equilibrium.

\subsection{Dependent Variable}

\subsubsection{Employment Level}

The proportion of the labor drive this is employed undertaken. The employment level is, without doubt, one of the financial indicators that economists examine to lend a hand to perceive the state of the financial system. Employment is a freelance during which one individual, the employee, agrees to accomplish paintings for any other, the employer.

\subsection{Independent Variables \\ 3.5.1. Foreign aid}

From all over the world capital items, money, and other gifts sent for the welfare of the recipient country. Aid has many forms it could be in the form of economic, military, or any emergency condition.

\subsubsection{Gross Domestic Product}

Gross domestic product is termed as the "total cost of all completed goods and services produced the country in a stipulated period of time" (usually a year).

\subsubsection{Gross fixed capital formation}

"Gross fixed capital formation (formerly gross domestic fixed) improvements (fences, ditches, drains, and so on); plant machinery and equipment purchases; includes lands of roads, railways, and the like, including schools, offices, hospitals, private residential dwellings, and commercial and industrial buildings".

\subsubsection{Participation Rate}

It defines the "Labour Force Participation Rate" as the proportion of the nation's population 16 and over operating or searching for paintings. It is made up of our minds via 
demography, maximum notably the share of the grownup population of top operating age, normally 25 to 54 .

\subsubsection{Public Expenditure}

"Public Expenditure" is defined as "spending made by the government of a country on collective needs and wants such as a pension, provision, infrastructure, etc.".

\subsubsection{Exports}

An export is "a function of international trade whereby goods produced in one country are shipped to another country for future sale or trade. The sale of such goods adds to the producing nation's gross output. If used for trade, exports are exchanged for other products or services".

\section{RESULTS AND DISCUSSION}

We have added estimation results of the association between foreign aid and employment generation in this chapter. In the first section unit root test was evaluated, and in the subsequent segment, there was a critique on ARDL for checking cointegration.

\subsection{Unit Root Analysis}

Though the ARDL bound test has no proper prerequisite to test the stationary sequence, the First table explained the ADF test results.

\section{Table 2}

Augmented Dickey-Fuller (Unit Root) Test

\begin{tabular}{|c|c|c|c|}
\hline Variable & $\begin{array}{c}\text { Level } \\
\text { Test Statistics } \\
\text { (Prob) }\end{array}$ & $\begin{array}{c}\text { First difference } \\
\text { Test Statistics } \\
\text { (Prob) }\end{array}$ & Decision \\
\hline LEMP & $\begin{array}{c}0.258218 \\
0.9725\end{array}$ & -4.385733 & $\mathrm{I}(1)$ \\
\hline LAID & $\begin{array}{c}0.9725 \\
-4.273680 \\
0.0093 *\end{array}$ & $\begin{array}{c}0.0001 * \\
-6.335294 \\
0.0000 * *\end{array}$ & $\mathrm{I}(0)$ \\
\hline LF PARTI & $\begin{array}{c}-2.960257 \\
0.0522\end{array}$ & $\begin{array}{c}-9.793317 \\
0.0000 * *\end{array}$ & $\mathrm{I}(1)$ \\
\hline LEXPR & $\begin{array}{c}-4.185413 \\
0.0145^{*}\end{array}$ & $\begin{array}{c}-3.303879 \\
0.0240 *\end{array}$ & $\mathrm{I}(0)$ \\
\hline LGOVT EXP & $\begin{array}{c}-0.533428 \\
0.8726\end{array}$ & $\begin{array}{c}-2.736742 \\
0.0077 *\end{array}$ & $\mathrm{I}(1)$ \\
\hline LGFCF & $\begin{array}{c}-0.424041 \\
0.8941\end{array}$ & $\begin{array}{c}-3.970195 \\
0.0002 * *\end{array}$ & $\mathrm{I}(1)$ \\
\hline LGDP & $\begin{array}{c}0.392265 \\
0.9798\end{array}$ & $\begin{array}{c}-4.410282 \\
0.0001 * *\end{array}$ & $\mathrm{I}(1)$ \\
\hline
\end{tabular}

Note: The signs $* *$ and $*$ indicated that the coefficient is significantly different from zero at $1 \%$ and $5 \%$ probability, respectively.

The ARDL bound test required three steps to verify. In the first step, long term co integrating existence is checked by seeing the number of variables in the equation. One thing needed to understand is that "if the estimated F statistics go higher than bound prices would be higher and thus null hypothesis of no cointegration is rejected". Whereas, if the estimated $f$ statistics show smaller than the decrease of essential value and the null hypothesis of no cointegrated cannot be rejected, which shows that variables did not seem co-integrated. Moreover, Inconclusiveness of F-statistics decided when it falls between lower and upper bands. The second step is used to estimate the long run, and the third step is used to calculate the short-run association between variables. In table 1 , the variables are found stationary at different levels. No variable is found at I(2), so we have no fear of spurious results. AID and EXPR are found stationary at a level whereas, the variables EMP, LF PARTI, GOVT EXP, GFCF and GDP are found stationary at first difference. This leads to the execution of the ARDL method of cointegration analysis to estimate the model. 


\subsection{ARDL Bounds Testing Analysis}

\subsubsection{Lag length Criteria}

The lag length should be determined properly because it is needed by cointegration for estimation of long-run cointegration model to get efficient results. We determine the optimal lag length for the estimation process.

\section{Table 3}

VAR Lag Order Selection Criteria (CABECT and FDI)

\begin{tabular}{ccc}
\hline$L a g$ & $A I C$ & $H Q$ \\
\hline 0 & -18.52608 & -18.43422 \\
1 & -26.17716 & -25.53415 \\
2 & $-26.42404^{*}$ & $-25.22988^{*}$ \\
\hline
\end{tabular}

*Signposts lag order selected by the criterion

AIC = "Akaike Information Criterion."

$\mathrm{HQ}=$ "Hannan-Quinn Information Criterion"

The Lag length of I (2) is selected for estimation using the Akaike Information Criterion and Hannan-Quinn Information Criterion, respectively. In the ARDL model, we have observed that F-statistics is higher than the upper bound. We have the value for significance is $1 \%, 2.5$ $\%, 5 \%$ and $10 \%$. So, by the above information of results, it is stated that the null hypothesis of no Co-integration is rejected because there is a relationship of variables in Co-integration. Table 3 showed the existence of cointegration between the variables.

Model Estimated Model (EMP,AID,EXPR,GDP,GFCF,GOVT-EXPN,LLF-PARTI )

Table 4

ARDL bounds Testing Analysis

\begin{tabular}{ccc}
\hline Critical bound values & Lower Bound Value & Upper Bound Value \\
\hline $10 \%$ & 1.81 & 2.93 \\
$5 \%$ & 2.14 & 3.34 \\
$2.5 \%$ & 2.44 & 3.71 \\
$1 \%$ & 2.82 & 4.21 \\
\hline
\end{tabular}

\subsubsection{Length (AIC)}

Table 5

Long and Short Results

\begin{tabular}{cccc}
\hline Variables & Coefficient & T-statistic & Prob \\
\hline LAID & 0.065208 & 4.967086 & 0.0016 \\
LEXPR & 0.105057 & 4.291349 & 0.0036 \\
LGDP & 0.142835 & 14.340342 & 0.0000 \\
LGFCF & 0.231481 & 9.144964 & 0.0000 \\
LGovt Exp & 0.021489 & 1.276693 & 0.2424 \\
LLF-PARTI & 0.067980 & 2.323420 & 0.0425 \\
ECM & Short Run Equation & -9.172612 & 0.0000 \\
D(LAID) & -0.645776 & 3.757193 & 0.0071 \\
D(LEXPR) & 0.012232 & 7.392782 & 0.0002 \\
D(LGDP) & 0.115517 & 0.791237 & 0.4548 \\
D(LGFCF) & 0.037033 & 4.533879 & 0.0027 \\
D(LGovt Exp) & 0.093962 & 3.122928 & 0.0168 \\
D(LLF-PARTI) & 0.031063 & 4.469686 & 0.0012
\end{tabular}

\section{Model Diagnostics}


We have shown the long-term coefficients that are reported by the ARDL model. Foreign aid, Labour force participation, employment, exports, government expenditures, gross fixed capital formation confirmed by the long-term estimates they are comparable. The results showed that government expenditures, GDP, gross fixed capital formation, and labour force participation would be essential to generate employment. We shall reject the null hypothesis because of the foundations of the later one. We moved to the next step, and we got ECM. The results of the ECM are shown in table 4.

From the tables, we conclude that foreign aid, exports, gross domestic product, gross fixed capital formation, government expenditures, labour force participation are those variables that have a great impact in the long term and have a positive sign for employment generation. The variable, fixed capital formation, is showing the strongest relationship with the dependent variable employment generation, while the least strong relationship is found between government expenditure and employment. Likewise, the short-run coefficients for all the independent variables are exhibiting significant positive relation with the dependent variable 'employment generation'. The empirical results are in favour of the hypothesis developed about variables. The error correction time period is statistically important because it has a (-) sign. This is a desirable situation, which satisfies the short-run equilibrium condition of the model where the variables are stable and consistent. The ECM coefficient has value -0.645776 . The $p$-value for JB normality test is large, so we accept the null hypothesis of residuals being normally distributed around mean, i.e. the data is normal for this research. The probability value for the correlation test is also satisfying that the model is free of serial correlation. So, it is suggested that in the end, all the investigative tests showed, model, satisfied all the described experiments.

\section{CONCLUSION AND RECOMMENDATIONS \\ 5.1. Conclusion}

This research has focused on the key aim that was the impact of foreign aid on employment generation for the period of 1980-2015. The LFS has used four categories of employment. The four categories are employees, self-employed, unpaid workers of family, and participants in government-funded training schemes. We have implemented the ADF (Augmented Dicky Fuller) for checking the behaviour of variables, and autoregressive distributive lag fashion is used to research error correction time frames in the fashion. In this analysis, we used one dependent variable EMP. In our study, something clears it that employment has a positive association with foreign aid.

We concluded from the results that fiscal decentralization has the right effect on employment generation while it will not consider income decentralization suitable for employment generation. Poverty and inequality are decreasing the employment in Pakistan, so fiscal autonomy is essential for growing additional employment choices in Pakistan. The findings suggested that domestic funding and export expansion are essential folks in bettering economic enlargement in Pakistan. There is a pleasant relationship between employment and in line with capita GDP.

\subsection{Recommendations}

- There should be coverage that may build up male and female education so they can get more employment is undoubtedly associated with them according to capita GDP.

- When more inhabitants have employment, it highly will increase per capita GDP.

- The Government of Pakistan should encourage foreign aid, and there is much need of a pleasant environment and good incentives to attract investors.

- Ministry of overseas employment should make an association for developing jobs for our skilled and trained workers in the international labor markets to raise workers' remittances. 


\section{Conflict of Interests/Disclosures}

The authors declared no potential conflicts of interest w.r.t the research, authorship and/or publication of this article.

\section{REFERENCES}

Ali, S., \& Ahmad, N. (2013). A time series analysis of foreign aid and income inequality in Pakistan. Ali, Sharafat \& N. Ahmad (2013). A Time Series Analysis of Foreign Aid and Income Inequality in Pakistan. Global Journal of Management and Business Research, 13(5), 11-20.

Anwar, T. (2004). Recent macroeconomic developments and implications for poverty and employment in Pakistan: The cost of foreign exchange reserve holdings in South Asia.

Bakare, A. (2011). The macroeconomic impact of foreign aid in Sub-Saharan Africa: The case of Nigeria. Business and management review, 1(5), 24-32.

Bhattacharjee, D. (2015). China Pakistan economic corridor. Available at SSRN 2608927.

Brecher, I., \& Abbas, S. A. (2005). Foreign aid and industrial development in Pakistan (Vol. 1): Cambridge University Press.

Butt, R., \& Javid, A. Y. (2013). Foreign Aid and the Fiscal Behaviour of Government of Pakistan: Pakistan Institute of Development Economics.

Chenery, H. B., \& MacEwan, A. (1966). Optimal patterns of growth and aid the case of Pakistan. The Pakistan Development Review, 6(2), 209-242.

Ellahi, N., \& Ahmad, M. (2011). Testing the joint impact of foreign aid and foreign direct investment on overtime economic growth of Pakistan. Paper presented at the International Conference on Business and Economic Research. Langkawi Malaysia: World Research Agency.

Faridi, M. Z., Chauhdhry, M., \& Ansari, F. N. (2012). The Impact of Fiscal Decentralisation, Inequality and Poverty on Employment: Evidence from Pakistan. Pakistan Journal of Social Sciences, 32(2), 357-369.

Hye, Q. M. A., Shahbaz, M., \& Hye, A. (2010). Foreign capital inflow and economic growth nexus: A case study of Pakistan. IUP Journal of Applied Economics, 9(1), 16.

Ishfaq, M. (2004). Aid effectiveness, debt capacity and debt management in the economy of Pakistan. a PhD dissertation at Quad-e-Azam University, Islamabad.

Javid, M., \& Qayyum, A. (2011). Foreign aid and growth nexus in Pakistan: The role of macroeconomic policies.

Kanioura, A., \& Turner*, P. (2005). Critical values for an F-test for cointegration in a multivariate model. Applied Economics, 37(3), 265-270.

Khan, M. A., \& Ahmed, A. (2007). Foreign aid-blessing or curse: Evidence from Pakistan. The Pakistan Development Review, 215-240.

Mahmood, A. (1997). The role of foreign aid in economic development of Pakistan (1960-61 to 1994-95). Pakistan Economic and Social Review, 57-90.

Malik, S., Chaudhry, I. S., \& Javed, H. I. (2011). Globalization and Employment: Evidence from Pakistan. Pakistan Journal of Social Sciences (PJSS), 31(2).

Mallik, G. (2008). Foreign Aid and Economic Growth: A Cointegration Analysis of the Six Poorest African Countries. Economic Analysis \& Policy, 38(2).

Mullick, H. (2004). US foreign aid and economic growth: A post-9/11 case study of Pakistan as a key ally in the war against terrorism. Paper presented at the Proceedings of the Pennsylvania Economic Association Conference 2004.

Nowak-Lehmann, F., Martínez-Zarzoso, I., Herzer, D., Klasen, S., \& Cardozo, A. (2013). Does foreign aid promote recipient exports to donor countries? Review of World Economics, 149(3), 505-535.

Pesaran, M. H., Shin, Y., \& Smith, R. J. (2001). Bounds testing approaches to the analysis of level relationships. Journal of applied econometrics, 16(3), 289-326. doi: 10.1002/jae.616

Pesaran, M. H., \& Smith, R. (1995). Estimating long-run relationships from dynamic heterogeneous panels. Journal of econometrics, 68(1), 79-113.

Pohwani, P., Khoso, J. R., \& Ahmed, W. (2019). Impact of Foreign Aid on Economic Growth of Pakistan. Journal of Public Value and Administration Insights, 2(1), 18-25.

Rashid, M. K., Anwar, M., \& Torre, A. (2014). Foreign aid and fertility: an econometric analysis for Pakistan. World Applied Sciences Journal, 29(5), 660-666. 
Salman, A., \& Feng, H. X. (2010). FDI in Pakistan: Impact on GNP and capital financial account. Paper presented at the 2010 International Conference on Financial Theory and Engineering.

SARSOUR, S., NASER, R., \& ATALLAH, M. (2011). PALESTINE MONETARY AUTHORITY.

Shah, S. H., Hasnat, H., Cottrell, S., \& Ahmad, M. H. (2020). Sectoral FDI inflows and domestic investments in Pakistan. Journal of Policy Modeling, 42(1), 96-111.

Shahzad, A., Ahmed, T., Khiliji, B. A., \& Ahmed, I. (2011). Impact of Foreign Aid on Public Expenditure in Pakistan. Researchers World, 2(3), 98.

Shirazi, N. S., Mannap, T. A. A., \& Ali, M. (2009). Effectiveness of foreign aid and human development. The Pakistan Development Review, 853-862.

Siddiqui, R. (2006). The Pakistani economy: performance and challenges. The Muslim World, 96(2), 251.

Silk, J. I., \& Joutz, F. L. (1997). Short and long-run elasticities in US residential electricity demand: a cointegration approach. Energy economics, 19(4), 493-513.

World Bank, W. (2020). The World Bank. from https://databank.worldbank.org/source/worlddevelopment-indicators 